\title{
Polity age and political budget cycles: \\ Evidence from a Danish municipal reform
}

\begin{abstract}
Incumbent incentive for competence-signaling and lack of voter information are generally thought to be factors that increase the prevalence of political budget cycles. These mechanisms should be more prevalent in new political units. Since the creation of new political units is rarely exogenous, however, serious endogeneity issues would be an issue for empirical studies of this subject. To overcome these problems, I use a Danish local government reform—which amalgamated some (but not all) Danish municipalities, thereby creating new political units—in a way that is arguably quasiexperimental to study whether political budget cycles are larger in new political units. Contrary to theoretical predictions, political budget cycles seem to be of a smaller scale in the new municipalities, but only regarding budget cycles in budgetary overruns. The findings are of wider interest for discussions the mechanisms behind context-conditional political budget cycles.
\end{abstract}

Keywords: Political budget cycles; conditional political budget cycles; local government budget; budgetary overruns; quasi-experiment; local government reform 


\section{Introduction}

Are electorally motivated increases in public deficits - political budget cycles-larger in new political units? The article in hand investigates this question by exploiting using a Danish municipal reform that caused an exogenous shock to the age structure of Danish municipalities.

Political budget cycles - the occurrence of election-year-induced increased spending/decreased revenue collection and subsequent deficits - is arguably one of the most studied subjects in political economy and to some extent political science. This literature usually builds on the broader theoretical and empirical literature on the political business cycle, election-induced economic expansions due to loose fiscal or monetary policy (Nordhaus, 1975; Alesina, et al., 1997). ${ }^{1}$ While the empirical study of the occurrence and magnitude of political budget cycles usually focuses on budget deficits, electoral cycles have been detected in the composition of public spending (Katsimi and Sarantides, 2012), amendments to the initial budget proposal (Wehner, 2013), public wage increases (Matscke, 2003), and numerous other policy instruments; see Dubois (2016) for a recent review of the literature.

There is growing consensus in the study of political budget cycles, especially concerning budget deficits, that they are conditional on the incentive of the incumbent to run political budget cycles and the ability of voters to know about their occurrence. The importance of the incumbent incentive and voter information for the size of the political budget cycle underscores the cross-national findings that political budget cycles occur more frequently and are of a greater scale in less

\footnotetext{
${ }^{1}$ For a seminal model dealing specifically with budget cycles, see Rogoff (1990).
} 
developed countries (Shi and Svensson, 2006; Klomp and de Haan, 2013), as well as recent studies of subnational political budget cycles (Aidt et al., 2011; Klein and Sakurai, 2015). A similar crossnational finding is that political budget cycles are more prevalent in countries that recently transitioned into democracy, which suggests that the size of political budget cycles should vary with the age of the democratic regime (Brender and Drazen, 2005).

This article makes a related argument: that political budget cycles might be greater in new political units in general, including new subnational units, even despite lengthy democratic traditions. The main mechanism is that local policymakers in new polities, including new states and municipalities, would have a greater incentive to signal competence to voters due to a lower level of political reputation in the new political units. Moreover, voters in new polities have no information about previous electoral manipulation in the polity, even if they have considerable previous experience with democratic politics. The perceived net gains from electoral fiscal manipulation ${ }^{2}$ should therefore increase when political units are new and the political budget should consequently be larger.

The creation of new political units rarely occurs exogenously, however, which could cause serious problems with identifying a potential causal effect of polity age on the size of political budget cycles. This article overcomes this problem by using a reform to the municipal structure of Denmark in 2007, which amalgamated some but not all Danish municipalities, thereby creating new political units while leaving others intact, in a way that is arguably quasi-experimental, at least

\footnotetext{
${ }^{2}$ For a recent investigation of the electoral gain of political budget cycles at the local level, see Chortareas et al.
} (2016). 
regarding political budget cycles. This enables us to compare the magnitude of political budget cycles in the new amalgamated municipalities and the older municipalities within the same national political-administrative context to examine whether a potential difference in the size of political budget cycles changes over time.

However, the empirical results do not support the argument that new municipalities experience larger political budget cycles. To the contrary-if anything, new municipalities seem to have smaller political budget cycles than older municipalities, an effect which is only statistically significant for budget cycles in municipal budgetary overruns and seems to be driven mainly by the first election after the amalgamation. If a greater incumbent incentive for reputation-building actually existed in the new municipalities, they only seem to have affected budgetary management rather than pure election-year fiscal manipulation, and this effect seems to have been very shortlived. These results speak to the wider literature on conditional political budget cycles and cast some doubt on whether lack of voter information about the relevant political unit is a crucial mechanism behind the size of political budget cycles.

The structure of the article is as follows. Section 2 presents the theoretical argument for why we would expect political budget cycles to be larger in new political units. Section 3 describes the setting and context of the recent municipal reform in Denmark, which form the basis for the quasiexperimental design of the article and sets up the central hypotheses to be tested. Section 4 deals with the data and estimation method used to test the hypotheses. Section 5 contains the empirical results from the tests, while section 6 discusses the results. Section 7 concludes. 


\section{Theory}

The key mechanism for why we should expect political budget cycles to be larger in new political units is an increased incentive for incumbent politicians to signal competence to voters and build reputation. The core reason for incumbent politicians to engage in election-year manipulation in most theoretical models of political budget cycles is to signal competence to voters (Rogoff, 1990; Aidt et al., 2011) and/or preference alignment with voters (Drazen and Eslava, 2010). It would be very plausible that incumbent politicians in a new political unit have — at least perceivably —a lesser reputation in the context of their political unit, as they are less likely to be known among at least some voters ${ }^{3}$ in a new political unit than in an older political unit. These politicians therefore have a greater incentive to use the election-year expansion of public spending/decreases in taxation to signal competence and/or commitment to certain policies. These arguments are similar to those made about how the age of political parties reduces the extent to which parties run political budget cycles as incumbents. Since political parties establish their reputation and ability to credibly commit to certain policies and voters gain more information about the parties as time goes by, the age of incumbent government parties should reduce their incentive to run political budget cycles (Hanusch and Keefer, 2014).

The information level of voters in new political units would be a related reason for the incumbent's incentive to run political budget cycles would be greater in new political units. Voters in newly formed political units, be they municipalities, provinces, or even states, will have no previous experience of election-year manipulation in their current political units and potentially low levels of knowledge about the general political functions of their newly formed polity. In turn, this would

\footnotetext{
${ }^{3}$ If, e.g., the new political unit was formed from an amalgamation of two or more previous political units.
} 
incentivize incumbent politicians to exploit this lack of knowledge, as voters are less aware that election-year increases in public spending/decrease in taxation are due to short-term electoral manipulation rather than incumbent competence. As the political units age, however, voters should increasingly learn about the fiscal manipulation of incumbents. The incumbent politicians would then adjust to the updated voter information and be less likely to run electorally induced fiscal expansion. The information level of voters is generally considered a key conditioning factor for the existence of political budget cycles and often has a central position in theoretical models (Shi and Svensson, 2006: pp. 1375-1379). The finding that government transparency, including budget transparency, seems to moderate political budget cycles (Alt and Lassen, 2006; Klomp and de Haan, 2013, pp. 336-337) also suggests that a lack of voter information could be an important driver of political budget cycles. Nonetheless, the potential relation between voter information and the age of the relevant political units and the subsequent effects on political budget cycles have not been rigorously studied.

According to these arguments, we should expect incumbent politicians in new political units to run larger political budget cycles. As evidence suggests that voters adjust their evaluation of incumbent performance as time passes (Nannestad et al., 2003) and potentially gain more knowledge about past electoral manipulation, however, it seems plausible that both the reputation-building mechanism and the information mechanism will wane over time. ${ }^{4}$ Consequently, as new polities age, the political budget cycle ought to decline.

\footnotetext{
${ }^{4}$ This approach to political budget cycles could also explain the findings of Treisman and Gimpelson (2001), who find that Russian incumbents seemed to change the policy tool to manipulate the economy for each election during national elections in the 1990s.
} 
In summary, then, there is reason to expect electoral budget cycles to be of a greater magnitude in new political units - sovereign countries as well as subnational units, such as provinces and municipalities - as the incentive for incumbent politicians to signal competence is greater and voters have less context-specific political knowledge. There is also reason to expect that as new political units age, the extent of the electoral manipulation decreases as politicians acquire more credible reputations and voters obtain more information.

Consistent with the view that a new political regime makes fiscal manipulation more attractive to incumbent politicians, evidence from Israeli municipal elections suggests that voters' electoral tolerance for debt increases are higher in new political units (Brender, 2003: p. 2201), although these results might be biased by unobservable characteristics of the new municipalities.

Consequently, the arguments about polity age and political budget cycles are difficult to assess empirically due to serious endogeneity problems. The creation of other types of new political units is clearly not exogenous to voter information and political experience. Since new political units, national and subnational alike, are not created randomly, the new polity hypothesis regarding political budget cycles is difficult to verify robustly. This article is able to exploit a quasiexperimental setting to investigate whether political budget cycles are indeed larger in new political units. 


\section{The quasi-experimental setting: Danish municipal reform}

In 2007 a new municipal structure was introduced in Denmark reducing the number of municipalities from 271 to 98 with the explicit objective of forming on average larger municipalities. 239 of the previous municipalities were amalgamated to form 66 new municipalities, whereas 32 municipalities were left untouched. With the exception of the two island municipalities of Bornholm (created when five municipalities were amalgamated in 2003) and Ærø (created when two municipalities amalgamated in 2006), ${ }^{5}$ the 32 municipalities had existed since the last Danish municipal reform in the early 1970 s. ${ }^{6}$ While the old municipalities were technically free to amalgamate into municipalities of a certain size as determined by the central government, Bhatti and Hansen (2011) have demonstrated how citizens' commuting patterns, municipal size, and distance to each other predict amalgamation, whereas economic and political factors do not seem to matter. Especially with respect to electoral budget cycles, this renders the reform a quasiexperimental setting (Lassen and Serritzlew, 2011: pp. 243-244).

While this Danish municipal reform has been used to study the effect of polity size on the internal political efficacy of citizens (Lassen and Serritzlew, 2011), scale effects in the cost of public administration and services (Blom-Hansen et al., 2014; Blom-Hansen et al., 2016), common-pool aspects of public expenditure decisions (Blom-Hansen, 2010; Hansen, 2014), as well as general fiscal outcomes (Hansen et al., 2014), it has not been utilized to study whether the age of a political unit affects the scale of political budget cycles. Given that the reform created new political units out

\footnotetext{
${ }^{5}$ For the purpose of data analysis, $\mathcal{E} \varnothing \varnothing$ is coded as amalgamated while Bornholm is not.

${ }^{6} \mathrm{~A}$ full description of the reform and amalgamation process can be found in Bhatti and Hansen (2011: pp. 214-217).
} 
of some but not all of the municipalities and consequently was an exogenous shock to the age structure of a set of subnational units within the same national political-administrative frame, together with the fact that the amalgamation of municipalities seems unrelated to the potential political and economic confounders of political budget cycles (Bhatti and Hansen, 2011), its quasiexperimental nature makes it ideal for studying the effect of the age of political units on the scale of political budget cycles.

The reform should plausibly have changed the information level of voters in the new municipalities given that the administrative units and to some extent the local politicians were new and the new municipalities would have no independent history of political budget cycles. This should increase the perceived electoral benefit of running political budget cycles, since local politicians would have a greater incentive to appear competent and build their reputations in the short run, as they would on average be less known by their potential voters than politicians from non-amalgamated municipalities. Furthermore, voters in amalgamated municipalities could be perceived by local politicians to be less informed about previous electoral fiscal manipulation, which would further increase the incentive to run political budget cycles. However, the previous democratic experiences of the local citizens would be unchanged in both new and older municipalities, so if this general democratic experience mechanism drives the effect of being a new polity on the size of political budget cycles (Brender and Drazen, 2005), we should not expect the size of budget cycles to differ between the amalgamated and non-amalgamated municipalities. This reform is therefore ideal for investigating whether political budget cycles are larger in new polities due to an increased incentive for incumbents to appear competent and the lack of polity-specific information available to voters. 
We would expect the new municipalities to have higher levels of political budget cycles and this difference between new and old municipalities to decrease for with each subsequent election. The theoretical argument about polity age and political budget cycles gives rise to two hypotheses in the Danish municipal context:

H1: The magnitude of political budget cycles should be greater in amalgamated municipalities.

H2: The effect of amalgamation on political budget cycles should decline from the first to the second election after the reform.

\section{Data and estimation}

The data used to test the relevant hypotheses in the Danish municipal setting consists of all 98 Danish municipalities in the years 2007-2013. Two different measures of potential local political budget cycles are used: One is municipal budgetary overruns measured as the difference between budgeted and realized fiscal surplus in Danish Kroner (DKK) per municipal citizen, where previous research studying Danish municipalities has found considerable evidence of political cycles (Serritzlew, 2005). The other is the simple fiscal surplus in DKK per municipal citizen. Both measures only include current operating expenditures in current prices and exclude local investment expenditure. While studies of local political budget cycles often find cycles in public capital investment, since these are arguably visible to voters (Klein and Sakurai, 2015; Baskaran et al., 2016), Danish municipalities do not use accrual accounting for investment expenditures.

Consequently, investment expenditures in the within-year accounts might not always reflect building and maintenance activities - the activities that are actually visible to voters — within that specific year. This accounting issue might be a source of bias when trying to detect opportunistic electoral cycles in the official investment expenditures of Danish municipalities. Current operating 
expenditures, the main component of which is public wage expenditure, suffers much less from this potential source of bias. Other studies of expenditures in Danish municipalities also tend to only analyze current expenditure (Blom-Hansen et al., 2016: p. 819). The data is from the Danish National Institute for Municipal and Regional Research (KORA). Both budgetary overruns and realized fiscal surpluses largely exhibit a normal distribution, and I therefore choose to analyze them in unlogged format, which also makes interpretation of the later coefficients more intuitive.

The central independent variables are the occurrence of a municipal election and its interaction with the amalgamation status of the municipality. Municipal election is measured by a dummy, which takes the value 1 if there is a municipal election in this year. Two municipal elections were held (2009 and 2013) within the timeframe of the analysis. Danish municipal elections are all held simultaneously in the month of November and cannot be held early, so the use of a calendar year measure of election year should be sufficient to discover within-year political budget cycles. Amalgamation is also measured by a dummy, which takes the value 1 if the municipality was formed as a result of the 2007 reform.

In addition to the central independent variables, I include a variety of controls regarding political, economic, geographical, and demographic aspects of the municipality. The central political control is a dummy for whether the mayor is from a left-wing party. As economic variables, I include the local taxation base ${ }^{7}$ per citizen in DKK as a control for the relative wealth of the municipality and I also include a variable measuring the municipality's average expenditure need per municipal

\footnotetext{
${ }^{7}$ Average taxable income and wealth per municipal citizen.
} 
citizen $^{8}$ and a variable that measures the fiscal stress of the municipality. ${ }^{9}$ Geographical variables include the logs of population and population density. ${ }^{10}$ The demographic variables are the share of citizens with tertiary education, which can be seen as another potential proxy for the local citizens' general information level, the local unemployment rate, ${ }^{11}$ and the share of municipal citizens aged 65+. Finally, since amalgamation might have caused fluctuations in municipal debt and assets (Hansen et al., 2014), in later estimations I add a control for liquid assets per citizen measured in DKK as a control in some of the specifications. The different economic, geographical, and demographic variables are obtained from the Danish Ministry of the Interior. Descriptive statistics for all variables can be found in Table 1 .

\footnotetext{
${ }^{8}$ Measured in DKK and calculated by the Danish Ministry of the Interior. It is based on an assessment of the socioeconomic characteristics and the age structure of the municipality, including the share of children in low-education families and the general share of children and elderly.

${ }^{9}$ This is calculated as the expenditure need of the municipality, as defined by the Danish Ministry of the Interior, divided by the sum of the taxation per citizen base and municipal revenue from intergovernmental grants and the inter-municipal equalization scheme per citizen.

${ }^{10}$ Population density (unlogged) is the number of municipal citizens per square kilometer.

${ }^{11}$ Defined as the number of full-timed unemployed persons per 100 municipal citizens aged 17-64.
} 
Table 1. Descriptive statistics

\begin{tabular}{lrrrrr}
\hline & Mean & Std. Dev. & Min & Max & Observations \\
\hline Difference budgeted and realized surplus per citizen (DKK) & 220.31 & 1250.53 & -2655 & 13075 & 668 \\
Fiscal surplus per citizen (DKK) & 1632.64 & 1613.27 & -6565 & 17319 & 668 \\
Election & 0.29 & 0.45 & 0 & 1 & 668 \\
Amalgamated & 0.67 & 0.47 & 0 & 1 & 668 \\
Left-wing mayor & 0.50 & 0.50 & 0 & 1 & 668 \\
Tax base (DKK) & 157264.60 & 30012.01 & 115004 & 308944 & 668 \\
Fiscal stress & 0.31 & 0.04 & 0.18 & 0.40 & 668 \\
Expenditure need (DKK) & 52396.21 & 5535.35 & 38153.00 & 70817 & 668 \\
Log of population & 10.64 & 0.78 & 7.52 & 13.23 & 668 \\
Log of population density & 5.17 & 1.34 & 2.71 & 9.37 & 668 \\
Share of citizens with tertiary education & 22.96 & 8.33 & 12.6 & 51 & 668 \\
Unemployment rate & 3.82 & 1.39 & 1 & 8.7 & 668 \\
Share of citizens aged 65+ & 17.93 & 3.250823 & 10 & 33.20 & 668 \\
Liquid assets (DKK) per citizen & 1983.10 & 2654.36 & -6272 & 13269 & 668 \\
\hline Note: DKK is in current prices. & & & & &
\end{tabular}

The estimation is carried out using a municipal fixed-effect OLS regression ${ }^{12}$ with standard errors clustered at the municipal level and with time-fixed effects included in order to take a general trend in municipal budgetary overruns and deficits over the analyzed time period into account. The regression model is found in equation one with municipalities indexed by $i$ and year by $t$.

$$
Y_{i t}=\beta_{1} \text { Election }_{i t}+\beta_{2} \text { Election }_{i t} \text { Amalgamated }_{i}+\beta_{3} X_{i t}+\eta_{i}+\delta_{t}+\epsilon_{i t}
$$

Where $Y_{i t}$ is the measure of the level of the budget cycle, Election $i t$ is a dummy taking the value 1 if municipal election is held in municipality $i$ at time $t$ and 0 otherwise. Amalgamated is a dummy taking the value 1 if the municipality was formed out of amalgamation in 2007 and is therefore a new municipality and 0 otherwise. $X$ is a vector of controls, $\eta_{i}$ and $\delta_{t}$ are the municipal-fixed and time-fixed effects, respectively, while $\epsilon$ is the error term. Since a municipality's amalgamation

\footnotetext{
${ }^{12}$ Hausman and F-tests generally suggest that this approach is suitable. The results from the Hausman tests are reported in the fixed-effects regression tables below.
} 
status does not change over the analyzed period of time, it cannot be included separately in the fixed-effect estimation but its interaction ${ }^{13}$ with the election dummy enables the estimation of the effect of the amalgamation status on the scale of the local political budget cycle (Wooldridge, 2006: p. 488).

\section{Results}

\subsection{Main results}

Table 2 show the main results from the empirical tests. In columns 1 and 2, the electoral cycle in budgetary overruns is reported, while the potential electoral budget cycle in municipal fiscal surplus/deficits is reported in columns 3 and 4 . The political cycle in budgetary overruns is clearly visible from the models in columns 1 and 2 . The occurrence of an election causes the realized fiscal surplus to fall over DKK 4,000 per citizen short of the original budgeted amount. Contrary to expectations, however, amalgamation does not increase the size of the election effect, limiting it instead, as the coefficient of the interaction between election and amalgamation is positive. The effects are highly statistically significant and do not change substantially after controlling for liquid assets per municipal citizen in column 2 .

As regards the potential electoral cycle in fiscal surplus/deficit, a relatively large and statistically significant election effect can be found. An election in a non-amalgamated municipality lowers the municipal surplus by on average around DKK 5,000 per citizen. As with budgetary overruns, however, the status of a new municipality seems to limit rather than increase the scope of the

\footnotetext{
${ }^{13}$ Wald tests performed after each estimation generally suggest that the interactions are significant.
} 
electoral cycle. The election-amalgamation interaction is not statistically significant and the budget cycle regarding municipal deficits is apparently unaffected by whether the municipality was formed from the 2007 amalgamation. Of the control variables, only municipal expenditure need and the share of municipal citizens aged $65+$ seem to be statistically significantly associated with a larger realized versus budgeted surplus and larger fiscal surplus, which is surprising given how these are factors that should strain municipal expenditures. Given that transfers from the Danish central government and an intra-municipal equalization scheme are generally larger for higher levels of defined expenditure need, however, it might reflect revenue from this source. Increases in municipal population seem to increase the fiscal surplus, which is hardly surprising given that an increase in the population should lead to higher municipal tax revenue given the average taxation base. 
Table 2. Main results

\begin{tabular}{|c|c|c|c|c|}
\hline & Realized vs. & geted surplus & Fisce & plus \\
\hline & Model 1 & Model 2 & Model 3 & Model 4 \\
\hline Election & $\begin{array}{c}-4394.42 \\
(1147.55)^{* * *}\end{array}$ & $\begin{array}{c}-4382.02 \\
(1150.89)^{* * *}\end{array}$ & $\begin{array}{c}-5460.62 \\
(1761.61)^{* * *}\end{array}$ & $\begin{array}{c}-5450.18 \\
(1771.93)^{* * *}\end{array}$ \\
\hline Election $\times$ amalgamated & $\begin{array}{c}323.80 \\
(139.57)^{* *}\end{array}$ & $\begin{array}{c}295.31 \\
(140.54)^{* *}\end{array}$ & $\begin{array}{l}210.67 \\
(200.26)\end{array}$ & $\begin{array}{c}186.67 \\
(192.31)\end{array}$ \\
\hline Left-wing mayor & $\begin{array}{c}180.96 \\
(136.98)\end{array}$ & $\begin{array}{c}179.57 \\
(133.85)\end{array}$ & $\begin{array}{c}8.46 \\
(179.34)\end{array}$ & $\begin{array}{c}7.30 \\
(177.61)\end{array}$ \\
\hline Tax base & $\begin{array}{l}-0.02 \\
(0.02)\end{array}$ & $\begin{array}{l}-0.02 \\
(0.02)\end{array}$ & $\begin{array}{c}0.02 \\
(0.0318742)\end{array}$ & $\begin{array}{l}0.02 \\
(0.03)\end{array}$ \\
\hline Fiscal stress & $\begin{array}{c}-9298.63 \\
(16386.78)\end{array}$ & $\begin{array}{c}-7897.32 \\
(16589.39)\end{array}$ & $\begin{array}{c}25291.47 \\
(20101.96)\end{array}$ & $\begin{array}{c}26471.98 \\
(20474.37)\end{array}$ \\
\hline Expenditure need & $\begin{array}{c}0.36 \\
(0.07)^{* * *}\end{array}$ & $\begin{array}{c}0.36 \\
(0.08)^{* * *}\end{array}$ & $\begin{array}{c}0.35 \\
(0.13)^{* * *}\end{array}$ & $\begin{array}{c}0.35 \\
(0.13)^{* * *}\end{array}$ \\
\hline Log of population & $\begin{array}{c}591.36 \\
(4501.30)\end{array}$ & $\begin{array}{c}146.93 \\
(4438.95)\end{array}$ & $\begin{array}{c}14062.81 \\
(6721.37)^{* *}\end{array}$ & $\begin{array}{c}13688.40 \\
(6696.70)^{* *}\end{array}$ \\
\hline Log of population density & $\begin{array}{c}5124.21 \\
(3892.93)\end{array}$ & $\begin{array}{c}4272.85 \\
(3501.02)\end{array}$ & $\begin{array}{c}731.97 \\
(5966.57)\end{array}$ & $\begin{array}{c}14.76 \\
(5576.42)\end{array}$ \\
\hline Share of citizens with tertiary education & $\begin{array}{c}34.83 \\
(166.40)\end{array}$ & $\begin{array}{c}51.19 \\
(158.05)\end{array}$ & $\begin{array}{c}79.51 \\
(212.86)\end{array}$ & $\begin{array}{c}93.29 \\
(212.12)\end{array}$ \\
\hline Unemployment rate & $\begin{array}{c}184.01 \\
(104.65)\end{array}$ & $\begin{array}{l}164.25 \\
(98.84)^{*}\end{array}$ & $\begin{array}{l}153.48 \\
(136.38)\end{array}$ & $\begin{array}{c}136.83 \\
(134.20)\end{array}$ \\
\hline Share of citizens aged $65+$ & $\begin{array}{c}373.83 \\
(126.862)^{* * *}\end{array}$ & $\begin{array}{c}388.14 \\
(133.15)^{* * *}\end{array}$ & $\begin{array}{c}426.53 \\
(137.56)^{* * *}\end{array}$ & $\begin{array}{c}438.58 \\
(142.68)^{* * *}\end{array}$ \\
\hline Liquid assets (DKK) per citizen & - & $\begin{array}{l}-0.07 \\
(0.06)\end{array}$ & - & $\begin{array}{l}-0.06 \\
(0.06)\end{array}$ \\
\hline Municipal fixed effects & Yes & Yes & Yes & Yes \\
\hline Year fixed effects & Yes & Yes & Yes & Yes \\
\hline Number of municipalities & 98 & 98 & 98 & 98 \\
\hline Number of observations & 686 & 686 & 686 & 686 \\
\hline Hausman test value (p-value) & $\begin{array}{l}50.51 \\
(0.00)\end{array}$ & $\begin{array}{l}48.68 \\
(0.00)\end{array}$ & $\begin{array}{l}51.80 \\
(0.00)\end{array}$ & $\begin{array}{l}42.87 \\
(0.00)\end{array}$ \\
\hline Within R-square & 0.42 & 0.43 & 0.42 & 0.43 \\
\hline
\end{tabular}

Both realized vs. budgeted surplus and fiscal surplus are measured in current DKK per citizen. Municipal clustered standard errors in parentheses. $* \mathrm{p}<0.1, * * \mathrm{p}<0.05, * * * \mathrm{p}<0.01$

Judging from the results from Table 1, there seems to be no support in favor of Hypothesis 1; if anything, amalgamated municipalities experience smaller electoral budget cycles than nonamalgamated municipalities. However this relationship is only statistically significant for budgetary overruns rather than pure fiscal surplus/deficit. 


\subsection{Effects over time}

Surprisingly, being a new municipality due to amalgamation does not appear to increase the scope of local political budget cycles but rather to decrease it, an effect especially strong and statistically robust for budgetary overruns. No support is thus found for Hypothesis 1 . To explore these opposite than expected effects in relationship to hypothesis 2 , a distinction is made in Table 3 between the 2009 election, which was the first local election after the municipal reform, and the 2013 election, which was the next election. An electoral budget cycle is clearly present in both budgetary overruns and municipal deficit for both the 2009 and 2013 elections and there is still no statistically significant mediating effect of amalgamation status for fiscal surplus/deficit for either of the two elections. Amalgamation status does still seem to reduce the effect of election on budgetary overruns, although only for the 2009 election. So the effect of amalgamation status on the size of political budget cycles does not seem to be in line with the hypotheses. It does seem as though the mediating effect of amalgamation on the effect of elections on budgetary overruns does decrease from the first election after the amalgamation process, although the relative and modest coefficient size and level of statistical significance gives reason to interpret this with caution. ${ }^{14}$

\footnotetext{
${ }^{14}$ Wald test performed after the two in Table 3 show that we cannot reject the null hypothesis that the coefficients on the two election variables and the two interaction variables are similar. This is an additional reason to be cautious.
} 
Table 3. Election and amalgamation effects over time

\begin{tabular}{|c|c|c|}
\hline & $\begin{array}{c}\text { Realized vs. } \\
\text { budgeted surplus }\end{array}$ & Fiscal surplus \\
\hline 2009 election & $\begin{array}{c}-3755.96 \\
(675.10)^{* * *}\end{array}$ & $\begin{array}{c}-4558.07 \\
(948.55)^{* * *}\end{array}$ \\
\hline 2009 election $\times$ amalgamated & $\begin{array}{c}396.97 \\
(203.01)^{*}\end{array}$ & $\begin{array}{c}84.86 \\
(264.46)\end{array}$ \\
\hline 2013 election & $\begin{array}{c}-4203.03 \\
(1154.80)^{* * *}\end{array}$ & $\begin{array}{c}-5629.44 \\
(1714.18)^{* * *}\end{array}$ \\
\hline 2013 election $\times$ amalgamated & $\begin{array}{l}180.76 \\
(222.05)\end{array}$ & $\begin{array}{l}301.39 \\
(321.36)\end{array}$ \\
\hline Left-wing mayor & $\begin{array}{c}180.67 \\
(134.41)\end{array}$ & $\begin{array}{c}6.20 \\
(176.50)\end{array}$ \\
\hline Tax base & $\begin{array}{l}-0.02 \\
(0.02)\end{array}$ & $\begin{array}{c}0.03 \\
(0.03)\end{array}$ \\
\hline Fiscal stress & $\begin{array}{l}-7648.44 \\
(16571.02)\end{array}$ & $\begin{array}{c}26222.73 \\
(20558.11)\end{array}$ \\
\hline Expenditure need & $\begin{array}{c}0.36 \\
(0.08)^{* * *}\end{array}$ & $\begin{array}{c}0.35 \\
(0.13)^{* * *}\end{array}$ \\
\hline Log of population & $\begin{array}{l}-515.95 \\
(4837.97)\end{array}$ & $\begin{array}{c}14352.26 \\
(7210.75)^{* *}\end{array}$ \\
\hline Log of population density & $\begin{array}{c}4780.90 \\
(3641.20)\end{array}$ & $\begin{array}{c}-494.04 \\
(6077.72)\end{array}$ \\
\hline Share of citizens with tertiary education & $\begin{array}{c}39.79 \\
(158.89)\end{array}$ & $\begin{array}{c}104.7047 \\
(218.6787)\end{array}$ \\
\hline Unemployment rate & $\begin{array}{l}152.08 \\
(99.21)\end{array}$ & $\begin{array}{l}149.02 \\
(140.34)\end{array}$ \\
\hline Share of citizens aged $65+$ & $\begin{array}{c}390.42 \\
(134.03)^{* * *}\end{array}$ & $\begin{array}{c}436.30 \\
(143.89)^{* * *}\end{array}$ \\
\hline Liquid assets (DKK) per citizen & $\begin{array}{l}-0.07 \\
(0.06)\end{array}$ & $\begin{array}{l}-0.06 \\
(0.06)\end{array}$ \\
\hline Municipal fixed effects & Yes & Yes \\
\hline Year fixed effects & Yes & Yes \\
\hline Number of municipalities & 98 & 98 \\
\hline Number of observations & 686 & 686 \\
\hline Hausman test value (p-value) & $\begin{array}{l}39.82 \\
(0.00)\end{array}$ & $\begin{array}{l}36.82 \\
(0.00)\end{array}$ \\
\hline Within R-square & 0.43 & 0.43 \\
\hline
\end{tabular}

Both realized vs. budgeted surplus and fiscal surplus are measured in current DKK per citizen.

Municipal clustered standard errors in parentheses. ${ }^{*} \mathrm{p}<0.10,{ }^{* *} \mathrm{p}<0.05,{ }^{* * *} \mathrm{p}<0.01$. 
There does not appear to be any evidence in favor of the "new political unit" hypothesis with regards to political budget cycles in Danish municipalities. If anything, newly amalgamated municipalities had lower electoral budget cycles than older municipalities; an effect that is only statistically robust for budgetary overruns rather than pure fiscal surplus/deficits. The next section further tests the robustness of these findings.

\subsection{Robustness test}

The main results in Tables 2 and 3 do not appear to provide evidence in favor of Hypotheses 1 and 2 and the notion that political budget cycles should be smaller in new municipalities. On the contrary, electoral cycles in budgetary overruns seem to be smaller in amalgamated municipalities, at least in the first municipal election after the municipal reform. To test the robustness of the results, I conduct a number of robustness tests related to the measurement of the central independent variable and the estimation type used.

The election dummy is first replaced with a continuous variable in Table 4, which measures the number of years until the next municipal election as a way of testing the effect of electoral concerns across the entire electoral cycle. The results again show a clear electoral cycle, as both budgetary overruns decrease and fiscal surplus increase when the number of years until the next election increase. Turning to the interaction with amalgamation status, while the coefficients indeed suggest that amalgamation status might reduce the budget cycle, the effect being far greater for budgetary overruns, the interactions are not statistically significant. Throughout the entire electoral cycle, amalgamation status does not seem to affect the prevalence of electoral cycle fiscal manipulation. These results are somewhat more reconcilable with the results from Table 3, however, which 
suggests that the decreasing effect on amalgamation on the election effect of budgetary overruns was only statistically detectable in the first election after the amalgamation process and not across the whole analyzed period.

Table 4. Alternative measure of electoral cycle

\begin{tabular}{|c|c|c|}
\hline & $\begin{array}{l}\text { Realized vs. } \\
\text { budgeted surplus }\end{array}$ & Fiscal surplus \\
\hline Years until next election & $\begin{array}{c}2085.90 \\
(597.76)^{* * *}\end{array}$ & $\begin{array}{c}2615.08 \\
(912.20)^{* * * *}\end{array}$ \\
\hline Years until next election $\times$ amalgamated & $\begin{array}{l}-66.02 \\
(75.41)\end{array}$ & $\begin{array}{l}-15.61 \\
(92.70)\end{array}$ \\
\hline Left-wing mayor & $\begin{array}{l}180.23 \\
(133.18)\end{array}$ & $\begin{array}{c}7.60 \\
(177.04)\end{array}$ \\
\hline Tax base & $\begin{array}{l}-0.02 \\
(0.02)\end{array}$ & $\begin{array}{l}0.02 \\
(0.03)\end{array}$ \\
\hline Fiscal stress & $\begin{array}{l}-6235.04 \\
(16324.77)\end{array}$ & $\begin{array}{c}27786.39 \\
(20735.54)\end{array}$ \\
\hline Expenditure need & $\begin{array}{c}0.35 \\
(0.08)^{* * *}\end{array}$ & $\begin{array}{c}0.34 \\
(0.13)^{* *}\end{array}$ \\
\hline Log of population & $\begin{array}{l}-526.82 \\
(4312.92)\end{array}$ & $\begin{array}{c}13095.04 \\
(6873.03)^{*}\end{array}$ \\
\hline Log of population density & $\begin{array}{c}4384.67 \\
(3472.01)\end{array}$ & $\begin{array}{c}147.74 \\
(5633.72)\end{array}$ \\
\hline Share of citizens with tertiary education & $\begin{array}{c}48.10 \\
(157.30)\end{array}$ & $\begin{array}{c}88.49 \\
(214.17)\end{array}$ \\
\hline Unemployment rate & $\begin{array}{l}175.86 \\
(97.54)^{*}\end{array}$ & $\begin{array}{c}144.74 \\
(136.20)\end{array}$ \\
\hline Share of citizens aged $65+$ & $\begin{array}{c}387.41 \\
(132.74)^{* * * *}\end{array}$ & $\begin{array}{c}438.29 \\
(142.54)^{* * * *}\end{array}$ \\
\hline Liquid assets (DKK) per citizen & $\begin{array}{l}-0.07 \\
(0.06)\end{array}$ & $\begin{array}{l}-0.06 \\
(0.06)\end{array}$ \\
\hline Municipal fixed effects & Yes & Yes \\
\hline Year fixed effects & Yes & Yes \\
\hline Number of municipalities & 98 & 98 \\
\hline Number of observations & 686 & 686 \\
\hline Hausman test value (p-value) & $\begin{array}{l}49.72 \\
(0.00)\end{array}$ & $\begin{array}{l}42.42 \\
(0.00)\end{array}$ \\
\hline Within R-square & 0.43 & 0.42 \\
\hline
\end{tabular}

Both realized vs. budgeted surplus and fiscal surplus are measured in current DKK per citizen.

Municipal clustered standard errors in parentheses. $* \mathrm{p}<0.10,{ }^{* *} \mathrm{p}<0.05, * * * \mathrm{p}<0.01$. 
I then set out to test the robustness of the core results using an alternative estimation strategy. The full estimation from Table 2 is therefore redone in Table 5, including a lagged dependent variable ${ }^{15}$ and using a one-step system generalized method of moment estimation. With this estimation, the prevalence of a budget cycle in the public surplus/deficit remains clear and statistically significant. For budgetary overruns in column 1, however, the occurrence of a municipal election seems to increase the difference between realized and budgeted surplus and, thus, to reduce the size of budgetary overruns in contrast to the previous findings from the fixed-effect estimates. Neither of the two effects seem to be statistically significantly altered by the municipality's amalgamation status.

\footnotetext{
${ }^{15}$ Due to the relative short time span of the panel, the risk of Nickell bias when estimating a regression with both fixed effects and a lagged dependent variable would be substantial (Nickell 1981).
} 
Table 5. Generalized methods of moments estimation

\begin{tabular}{|c|c|c|}
\hline & $\begin{array}{l}\text { Realized vs. } \\
\text { budgeted surplus }\end{array}$ & Fiscal surplus \\
\hline Lagged dependent variable & $\begin{array}{c}0.23 \\
(0.08)^{* * *}\end{array}$ & $\begin{array}{c}0.24 \\
(0.08)^{* * *}\end{array}$ \\
\hline Election & $\begin{array}{c}559.45 \\
(234.23)^{* *}\end{array}$ & $\begin{array}{c}-1592.43 \\
(351.10) * * *\end{array}$ \\
\hline Election $\times$ amalgamated & $\begin{array}{c}150.07 \\
(155.68)\end{array}$ & $\begin{array}{l}-65.05 \\
(215.10)\end{array}$ \\
\hline Left-wing mayor & $\begin{array}{c}8.74 \\
(101.41)\end{array}$ & $\begin{array}{l}-18.04 \\
(112.04)\end{array}$ \\
\hline Tax base & $\begin{array}{l}-0.00 \\
(0.01)\end{array}$ & $\begin{array}{l}0.00 \\
(0.01)\end{array}$ \\
\hline Fiscal stress & $\begin{array}{l}-7933.39 \\
(7315.72)\end{array}$ & $\begin{array}{l}-1678.03 \\
(9245.47)\end{array}$ \\
\hline Expenditure need & $\begin{array}{l}0.04 \\
(0.04)\end{array}$ & $\begin{array}{l}0.01 \\
(0.05)\end{array}$ \\
\hline Log of population & $\begin{array}{l}-54.02 \\
(85.16)\end{array}$ & $\begin{array}{c}21.79 \\
(116.87)\end{array}$ \\
\hline Log of population density & $\begin{array}{l}-54.44 \\
(64.70)\end{array}$ & $\begin{array}{l}144.06 \\
(76.45)^{*}\end{array}$ \\
\hline Share of citizens with tertiary education & $\begin{array}{c}5.22 \\
(10.44)\end{array}$ & $\begin{array}{l}-4.56 \\
(13.30)\end{array}$ \\
\hline Unemployment rate & $\begin{array}{c}116.08 \\
(68.28)^{*}\end{array}$ & $\begin{array}{l}121.43 \\
(91.15)\end{array}$ \\
\hline Share of citizens aged $65+$ & $\begin{array}{l}-21.25 \\
(20.04)\end{array}$ & $\begin{array}{l}-42.59 \\
(25.53)^{*}\end{array}$ \\
\hline Liquid assets (DKK) per citizen & $\begin{array}{r}-0.020 \\
(0.02)\end{array}$ & $\begin{array}{l}-0.02 \\
(0.04)\end{array}$ \\
\hline Year fixed effects & Yes & Yes \\
\hline Number of municipalities & 98 & 98 \\
\hline Number of observations & 588 & 588 \\
\hline Arellano-Bond test for AR2 value (p-value) & $\begin{array}{l}-0.69 \\
(0.49)\end{array}$ & $\begin{array}{l}0.06 \\
(0.95)\end{array}$ \\
\hline Hansen statistics value (p-value) & $\begin{array}{l}21.33 \\
(0.17)\end{array}$ & $\begin{array}{l}35.62 \\
(0.00)\end{array}$ \\
\hline
\end{tabular}

Both realized vs. budgeted surplus and fiscal surplus are measured in current DKK per citizen. Robust standard errors in parentheses. $* \mathrm{p}<0.10, * * \mathrm{p}<0.05, * * * \mathrm{p}<0.01$.

The results from the robustness test again provide evidence against the two hypotheses and the argument that political budget cycles should be larger in new political units. They also suggest that the finding from Tables 2 and 3, which suggest that election-year budgetary overruns might be smaller in amalgamated municipalities, might be more uncertain than the core results suggest. 


\section{Discussion}

The statistical tests failed to confirm either of the two hypotheses on the effect of being a new political unit on the size of political budget cycles. Quite conversely, the findings suggest that—if anything - new municipalities had smaller political budget cycles but only with regards to budgetary overruns, an effect that was not particularly robust to alternative specifications.

If there was indeed any effect of amalgamation status on budget cycles among the analyzed municipalities, it was a decrease in the size of the budget cycles in budgetary overruns. The question then becomes why there was this potentially decreasing effect of budget cycles in budgetary overruns. One possibility is better and more efficient management, especially regarding municipal finances. Previous research examining the effect of municipal reform in Denmark finds that amalgamated municipalities seem to have improved their administrative efficiency (BlomHansen et al., 2014; Hansen et al., 2014: p. 210) and therefore perhaps also their capacity within budgetary management, which might lead to smaller budgetary overruns. Another possibility, which is in line with the reputation-building argument from Section 2 above, is that local politicians in amalgamated municipalities might have increased their efforts to prevent large budgetary overruns by making better and more realistic election-year budget forecasts to build a reputation for better fiscal management among voters in their new municipalities; while this reputation-building incentive had no effect on the existence or scale of election-year fiscal expansion. This might explain why the limiting effect of amalgamation on budgetary overruns is only statistically significant in the first election after the amalgamation of 2007, where the incentive to build reputation would plausibly be largest. 
Overall, however, the results do not provide any support in favor of the argument that political budget cycles are larger in new subnational political units, everything else being equal. The proposed mechanisms contributing to larger political budget cycles in new political units - that the incumbent local politicians had increased incentive to acquire reputation and that voters lacked information about the previous actions of local politicians in new political units and regimes-do not seem to hold for the new Danish municipalities created from the Danish municipal reform. These results suggest that incumbent reputation-building and the lack of context-specific information of previous budget cycles available to the voters in new political units might not be relevant mediating mechanisms for the size of political budget cycles. The interesting question then becomes why this is the case.

With regards to local incumbent reputation-building incentives, a potential explanation for the results of this article could be that the age of the relevant political parties - rather than the age of the political unit itself - conditions the incentive to acquire a reputation and thus the size of the political budget cycle, as the research by Hanusch and Keefer (2014) would suggest. This could reconcile the findings from the new Danish municipalities. While the municipal reform might have shifted the balance of power from one Danish party to another in some municipalities, it did very little to change the overall party system. Both before and after the reform, two major parties held the vast majority of the mayor's seats in Danish municipalities. These two parties, the Liberal Party and the Social Democrats, were established party brands with a history going back to 1870 and 1871 , respectively. The institutionalization of the Danish local party system might explain why new municipalities did not experience higher levels of political budget cycles in the years after the reform, as incumbents were able to draw on the reputational brand of their political parties. 
As regards the voter information mechanism, an explanation of the results could be that it is the overall experience with democratic politics rather than polity-specific information, which is the relevant mechanism for whether political budget cycles are thought to be effective. Consequently, experience with democratic politics rather than polity-specific political information might be the key conditioning factor for the size of political budget cycles. ${ }^{16}$ While citizens in new municipalities might have had little or no information about the previous functions of their new local polity, since the organization was new, their overall experience with democracy and local democratic politics would have been unchanged. ${ }^{17}$

\section{Conclusion}

Does the age of a political unit determine the magnitude of election-year fiscal manipulation? This article has investigated this specific explanation for political budget cycles by investigating a recent municipal reform in Denmark, which created new political units in a quasi-experimental manner. Contrary to expectations, however, there is no sign of a larger political budget cycle in the new municipalities compared to older municipalities. While municipal politicians might have had a relatively lower level of local reputation in new municipalities and voters in new municipalities might have had lower levels of context-specific political knowledge about their municipality than voters in non-amalgamated municipalities, these factors do not seem to have induced local

\footnotetext{
${ }^{16}$ Authors within this literature even seem to use the democratic experience and information mechanism somewhat interchangeably (Brender and Drazen, 2005: pp. 1289-1290). As the results in this article suggest, however, these two potential mechanisms could be very different and might not be perfectly correlated in different settings.

${ }^{17}$ Research by Lassen and Serritzlew (2011) suggest that the amalgamation process might have lowered internal political efficacy among local citizens; however, this change does not seem to have had any significant impact on local political budget cycles.
} 
politicians to run larger political budget cycles. On the contrary, with regards to budgetary overruns, new municipalities might have had significantly smaller election-year budgetary overruns, at least in the first election after the reform.

The findings of this article speak to general literature on conditional political budget cycles and the mechanisms driving the conditionality of political budget cycles. Incumbent incentive and voter information are often thought to be crucial factors in this area (Shi and Svensson, 2006), but the results here suggest that the precise operationalization and mechanism behind these conditional factors might matter greatly for whether they actually affect the existence and size of political budget cycles. The results suggest that context-specific political experience and the knowledge of citizens might matter less than their overall experience with democratic politics (Brender and Drazen, 2005) and/or the age and structure of the relevant party system (Hanusch and Keefer, 2014) for the incentive for incumbents to engage in election-year fiscal manipulation. Investigating these issues in other subnational contexts might be a fruitful venue for future research.

Future research on both cross-national and local political budget cycles could pay more attention to the proposed mechanisms driving the apparent conditionality of political budget cycles (de Haan and Klomp, 2013) and develop research designs to investigate these mechanisms causally. This article is a modest step in this direction. 


\section{Acknowledgement}

I thank Ulrik Kjær and Søren Kjær Foged for generously sharing their data as well as for their help and advice. I also thank participants at the Danish Public Choice Workshop 2016, Benjamin Egerod, two anonymous reviewers and the editor of European Journal of Political Economy for helpful suggestions and advice. All errors remain my own. 


\section{References}

Aidt, T.S., Veiga, F.J., Veiga, L.G., 2011. Election results and opportunistic policies: a new test of the rational political business cycle model. Public Choice 148, 21-44.

Alesina, A., Roubini, N., Cohen, G.D., 1997. Political Cycles and the Macroeconomy. Cambridge: MIT Press.

Alt, J.E., Lassen, D.D., 2006. Transparency, political polarization, and political budget cycles in OECD countries. Am. J. Polit. Sci. 50, 530-550.

Baskaran, T., Brender, A., Blesse, S., Reingewertz, Y., 2016. Revenue decentralization, central oversight and the political budget cycle: evidence from Israel. Eur. J. Polit. Econ. 42, 1-16.

Bhatti, Y., Hansen, K.M., 2011. Who 'marries' whom? The influence of societal connectedness, economic and political homogeneity and population size on jurisdictional consolidations? Eur. J. Polit. Res. 50, 212-238.

Blom-Hansen, J., 2010. Municipal amalgamations and common pool problems: the Danish local government reform in 2007. Scand. Polit. Stud. 33, 51-73.

Blom-Hansen, J., Houlberg, K., Serritzlew, S., 2014. Size, democracy, and the economic costs of running the political system. Am. J. Polit. Sci. 58, 790-803.

Blom-Hansen, J., Houlberg, K., Serritzlew, S., Treisman, D., 2016. Jurisdiction size and local government policy expenditure: assessing the effect of municipal amalgamation. Am. Polit. Sci. Rev. 110, 812-831.

Brender, A., 2003. The effect of fiscal performance on local government election in Israel: 19891998. J. Public Econ. 87, 2187-2205. 
Brender, A., Drazen, A., 2005. Political budget cycles in new versus established democracies. $J$. Monetary Econ. 52, 1271-1295.

Chortareas, G., Logothesis, V., Papandreou, A.A., 2016. Political budget cycles and reelection prospects in Greece's municipalities. Eur. J. Polit. Econ. 43, 1-14.

Drazen, A., Eslava, M., 2010. Electoral manipulation via voter-friendly spending: theory and evidence. J. Dev. Econ. 92, 39-52.

Dubois, E., 2016. Political business cycles 40 years after Nordhaus. Public Choice 166, 235-259.

de Haan, J., Klomp, J., 2013. Conditional political budget cycles: a review of recent evidence. Public Choice 57, 387-410.

Hansen, S.W., 2014. Common pool size and project size: an empirical test on expenditures using Danish municipal mergers. Public Choice 159, 3-21.

Hansen, S.W., Houlberg, K., Hansen, L.H., 2014. Do municipal mergers improve fiscal outcomes? Scand. Polit. Stud. 37, 196-213.

Hanusch, M., Keefer, P., 2014. Younger parties, bigger spenders? Party age and political budget cycles. Eur. Econ. Rev. 72, 1-18.

Katsimi, M., Sarantides, V., 2012. Do elections affect the composition of fiscal policy in developed, established democracies? Public Choice 151, 325-362.

Klein, F.A., Sakurai, S.N. 2015. Term limits and political budget cycles at the local level: evidence from a young democracy. Eur. J. Polit. Econ. 37, 21-36.

Klomp, J., de Haan, J., 2013. Do political budget cycles really exist? Appl. Econ. 45, 329-341. 
Lassen, D.D., Serritzlew, S., 2011. Jurisdiction size and local democracy: Evidence on internal political efficacy from large-scale municipal reform. Am. Polit. Sci. Rev. 105, 238-257.

Matschke, X., 2003. Are there election cycles in wage agreements? An analysis of German public employees. Public Choice 114, 103-135.

Nannestad, P., Paldam, M., Rosholm, M., 2003. System change and economic evaluations: a study of immigrants and natives in Israel. Elect. Stud. 22, 485-501.

Nordhaus, W., 1975. The political business cycle. Rev. Econ. Stud. 42, 169-190.

Nickell, S., 1981. Biases in dynamic models with fixed effects. Econometrica 49, 1417-1426.

Rogoff, K., 1990. Equilibrium political budget cycles. Am. Econ. Rev. 80, 21-36.

Serritzlew, S., 2005. Breaking budgets: an empirical examination of Danish municipalities. Financial Acc. \& Man. 21, 413-435.

Shi, M., Svensson, J., 2006. Political budget cycles: Do they differ across countries and why? J. Public Econ. 90, 1367-1389.

Treisman, D., Gimpelson, V., 2001. Political business cycles and Russian elections, or the manipulation of "Chudar." Br. J. Polit. Sci. 31, 225-246.

Wehner, J., 2013. Electoral budget cycles in legislatures. Legis. Stud. Q. 4, 545-570.

Wooldridge, J.M. 2006. Introductory Econometrics: A Modern Approach. Mason: Thomson Higher Education. 